\title{
On the Optimal Trade Tariffs among Nations
}

\author{
Luis F. Copertari \\ Computer Engineering Program, Autonomous University of Zacatecas (UAZ), Zacatecas, Mexico \\ Email: copertari@yahoo.com
}

How to cite this paper: Copertari, L.F. (2018) On the Optimal Trade Tariffs among Nations. Open Access Library Journal, 5: e4641.

https://doi.org/10.4236/oalib.1104641

Received: May 7, 2018

Accepted: June 5, 2018

Published: June 8, 2018

Copyright $\odot 2018$ by author and Open Access Library Inc.

This work is licensed under the Creative Commons Attribution International License (CC BY 4.0).

http://creativecommons.org/licenses/by/4.0/

\begin{abstract}
An optimization model for calculating trade tariffs based on the idea of a zero-balanced trade account for countries around the world is proposed. Specifically, countries in the G20 group of nations were analyzed. The results are scrutinized and reflected upon, and some ideas about policy to follow are proposed. Both the mercantilist and Keynesian points of view are considered.
\end{abstract}

\section{Subject Areas}

Managerial Economics

\section{Keywords}

Optimization, Linear Programming, Trade, Tariffs

\section{Introduction}

Typical textbooks on linear programming make emphasis on the theory and the models that can be used to solve specific given problems [1]-[8]. In the best case, they go from the "assumed system", which is an explanation of the problem with all the required data in place using tables and any other printed means necessary, to the problem formulation and the solution of problems [9] [10].

Nevertheless, these textbooks loose something very important: the ability to do consulting, being such consulting in this case recommendations for trade tariffs among nations based on an optimization linear programming model. This consulting ability requires the knowledge to be able to reach the "assumed system" from the "real system", because typically, it is difficult to go from reality to assumed system, to model and to implementation and, if necessary, back to reality and assumed system. Furthermore, it is also important to implement the solution obtained in reality and see if there is any gain. In that way, linear programming transcends its academic nature and becomes part of a real-world problem-solving methodology. The application of linear programming to real 
world problems is a never-ending process.

The problem being analyzed in this paper is balance neutral trade tariffs among a given group of nations. It is possible to calculate the "optimal" trade tariffs using a linear programming approach. In this paper, a model for calculating the optimal trade tariffs among nations is presented and thoroughly analyzed. This information comes from real life data, and such data is based on real problems facing nations.

The application of the LINDO/LINGO software to solve the trade tariffs case illustrates the advantages of LINDO/LINGO: it highlights all the important elements of a linear programming formulation and solving exercise.

\section{Methodology}

The use of linear programming to solve problems in the real world is a process with a feedback loop. It goes from "reality", which is the perception each stakeholder has, to the "assumed system", which is the explanation of such realization. Keep in mind that there are several perceptions of what the reality looks like, and all those perceptions need to be taken into account. Once the "assumed system" is clear, it is possible to formulate the problem into a "mathematical model", translate such model to the LINDO/LINGO (linear programming optimization software) syntax and to come up with solutions to be implemented in the real world. The advantage of linear programming is that it is a methodology that can be successfully applied to a wide variety of problems, including the case analyzed here of finding "optimal" trade tariffs among nations.

However, knowing how the linear programming (optimization) algorithm works allow the linear programming analysts to bring a novel perspective to the problem being solved. Thus, it may be possible to have the decision-makers in the real world realizing they may be trying to solve the wrong problem. This is the reason for a feedback loop between the "implementation in reality" stage and the "assumed system" stage. In the case of the "optimal" trade tariffs problem, the results obtained illustrate the difficulty of implementing such results in reality. It highlights the need for a deeper analysis involving trade neutral sectors. It also requires having information about the precedence and destinations of imports and exports for each sector if a specific trade policy to be implemented needs to be formulated. Figure 1 illustrates the linear programming optimization methodology. Such methodology goes from reality, to assumed system, to problem formulation, to mathematical model, to LINDO compatible syntax formulation, to implementation in reality and, in this case, back to assumed system because it is not possible to implement in reality the results obtained since more information and a deeper analysis, specific to a given country (possibly the United States of America), is required.

\section{The G20 Group of Nations}

The G20 (or group of twenty) is an international forum for the governments and central bank governors from Argentina, Australia, Brazil, Canada, China, 


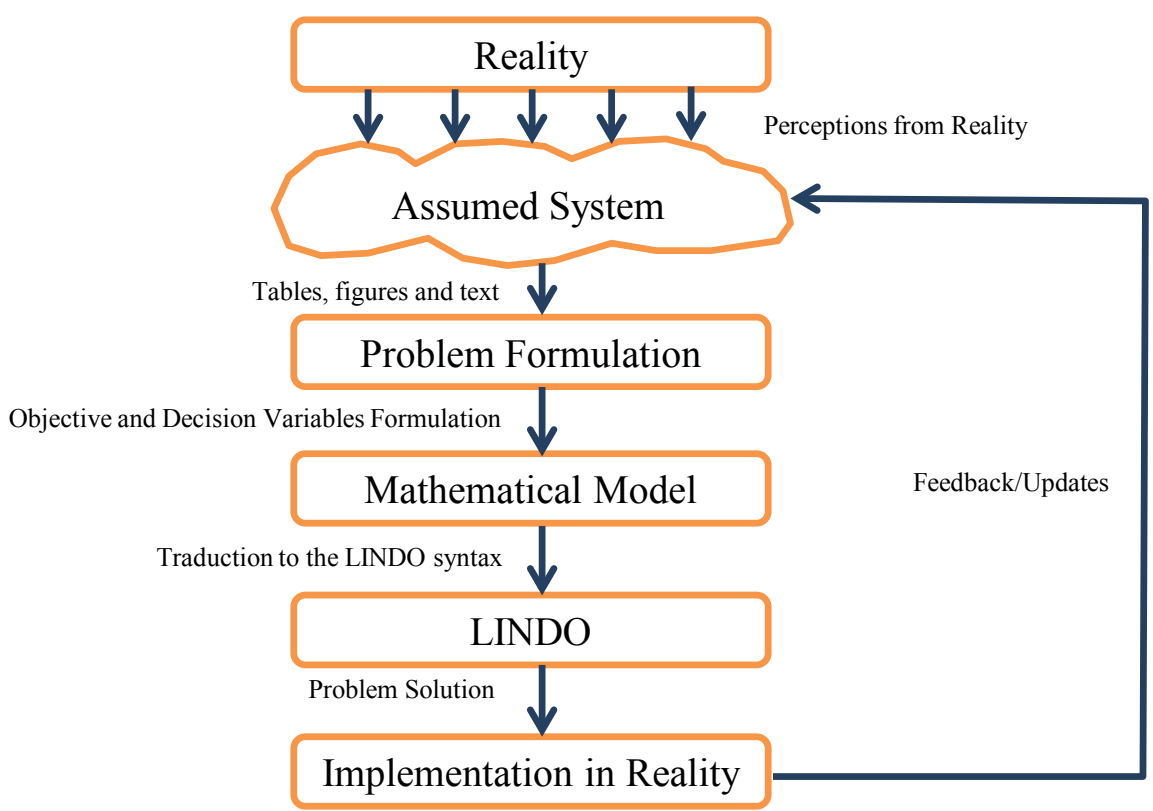

Figure 1. The linear programming approach cycle.

France, Germany, India, Indonesia, Italy, Japan, Mexico, the Republic of Korea, the Russian Federation, Saudi Arabia, South Africa, Turkey, the United Kingdom, the United States and the European Union [11].

Data for the Gross Domestic Product (GDP) for all these nations, with the exception of the European Union, since it is not a nation or South Korea, because there was no data available for imports and exports [12] [13] was collected. Such data is shown in Table 1 [14]. In order to be able to consider all 18 nations, the GDP for 2016 was used, since there is data for imports and exports for 2016. Figure 2 illustrates the participation of each of these economies.

\section{Trade Balances}

Data for the trade balances (imports and exports) was gathered. Such data is shown in Table 2. This data can directly be used in order to build the tariffs trade model. Why can the total imports and exports can directly be used? Because only the total amount is necessary as input for the linear programming model proposed. The trade balance that needs to be neutral (equal to zero) corresponds to each country. Thus, in this paper, the specific sectors of each economy are not considered, but rather the overall total. It should be clear that in order to be able to actually make specific recommendations, more research is required. Although the values of each sector of each economy for imports and exports are available, there is no precedence for such values. In order to be able to implement the analysis carried out by this model, specific precedence (countries of origin) for each sector would have to be included, which is not available in the data collected. Thus, further research in order to do a deeper analysis, for a specific country, would be required. Nevertheless, the linear programming model is very useful as a framework of reference. 
Table 1. 2016 Gross Domestic Product of 18 nations in the G20 in billion USD (thousand million USD).

\begin{tabular}{|c|c|c|c|}
\hline Code & & Country & 2016 GDP (billion USD) \\
\hline 01ARG & 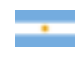 & $\underline{\text { Argentina }}$ & 545.124 \\
\hline 02AUS & 8 & $\underline{\text { Australia }}$ & 1258.978 \\
\hline 03BRA & & $\underline{\text { Brazil }}$ & 1798.622 \\
\hline 04CAN & & $\underline{\text { Canada }}$ & 1529.224 \\
\hline 05CHI & & China & $11,218.281$ \\
\hline 06FRA & & France & 2463.222 \\
\hline 07GER & & Germany & 3466.639 \\
\hline 08IDI & & $\underline{\text { India }}$ & 2256.397 \\
\hline 09IDO & & Indonesia & 932.448 \\
\hline 10ITA & & Italy & 1850.735 \\
\hline 11JAP & & $\underline{\text { Japan }}$ & 4938.644 \\
\hline 12MEX & & Mexico & 1046.002 \\
\hline 13RUS & & $\underline{\text { Russia }}$ & 1522.000 \\
\hline $14 \mathrm{SAU}$ & 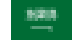 & $\underline{\text { Saudi Arabia }}$ & 639.617 \\
\hline 15SAF & & South Africa & 294.132 \\
\hline 16TUR & C. & Turkey & 857.429 \\
\hline 17UKM & 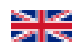 & United Kingdom & 2629.188 \\
\hline $18 \mathrm{USA}$ & 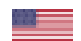 & United States & $18,569.100$ \\
\hline
\end{tabular}

\section{Tariffs Trade Model}

The basic model is to minimize tariffs. Let $\mathrm{E}$ be the exports and $\mathrm{M}$ the imports. Also, assume $\mathrm{X}$ is the trade tariff imposed on exports and $\mathrm{Y}$ is the trade tariff imposed on imports. Then, it follows the following lineal programming model, where the balance is forced to be zero. Although a previous analysis in which only sectors having a total value of goods (imported or exported) greater or equal to one billion were used, in the end, since only the real trade balance of each country was required, the actual value of the total imports and exports were used. This makes the analysis even more accurate.

$$
\text { Minimize: } \mathrm{X}+\mathrm{Y}
$$

Subject to:

$$
\begin{aligned}
& \mathrm{E}(1-\mathrm{X})-\mathrm{M}(1-\mathrm{Y})=\mathrm{B}=0 \\
& \mathrm{X} \leq 1 \\
& \mathrm{Y} \leq 1 \\
& \mathrm{X}, \mathrm{Y} \geq 0
\end{aligned}
$$

Thus, the model turns out to be as follows.

Minimize: $\mathrm{X}+\mathrm{Y}$

Subject to:

$$
\begin{aligned}
& \mathrm{EX}-\mathrm{MY}=\mathrm{E}-\mathrm{M} \\
& \mathrm{X} \leq 1 \\
& \mathrm{Y} \leq 1 \\
& \mathrm{X}, \mathrm{Y} \geq 0
\end{aligned}
$$




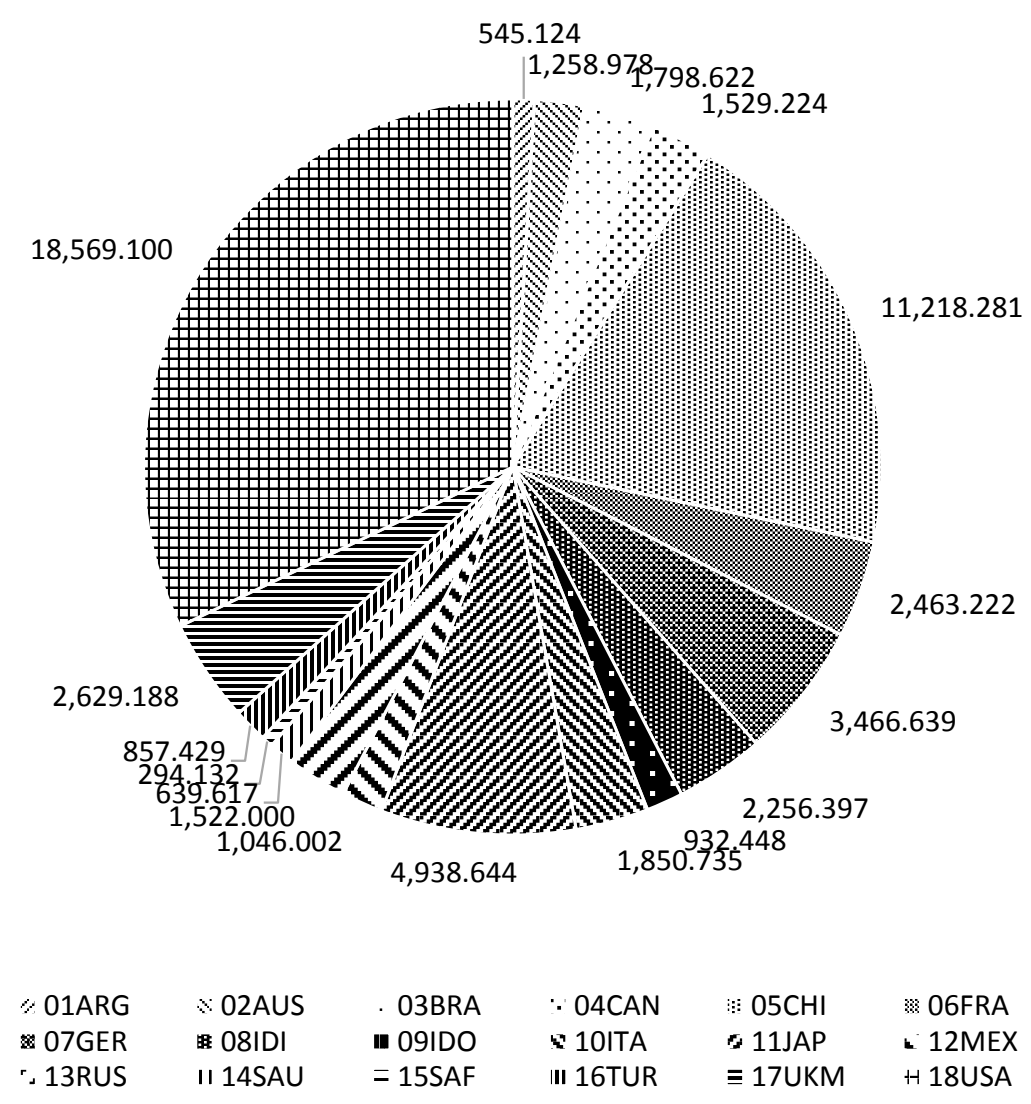

Figure 2. GDP share per nation.

The model actually used and solved using LINDO/LINGO is included in Appendix A. The corresponding output is shown in Appendix B. However, Table 3 summarizes the results.

\section{Discussion}

Countries with a positive trade balance shown in Table 2 indicate that total exports are greater than total imports. Having a negative trade balance indicates that imports are greater than exports. Argentina, with a trade balance of $\$ 2.124$ billion US dollars would be required to pay a very small amount of money on their exports indicated in Table 3 as $3.68 \%$. The problem of course, is who should receive such money. The case of Australia is similar, with a positive trade balance of $\$ 0.224$ billion US dollars, having to pay on their exports only $0.12 \%$. It could be said that Australia is almost perfectly balanced in their trade. This should of course be the ideal situation from a mercantilist point of view.

Indonesia also has a very small positive trade balance of $\$ 8.837$ billion US dollars, which would imply paying on their exports $6.12 \%$. Getting a little further away is Japan with a positive trade balance of $\$ 38.008$ billion US dollars, which would theoretically require them to pay $5.89 \%$ on their exports. Italy also has a positive trade balance of $\$ 56.951$ billion US dollars, which would mean for them to pay $12.34 \%$ on their exports. 
Table 2. Imports and exports in thousand million (billion) US dollars.

\begin{tabular}{|c|c|c|c|c|c|c|}
\hline Code & Country & Variable & Imports & Variable & Exports & Balance \\
\hline $01 \mathrm{ARG}$ & Argentina & M01ARG & $\$ 55.610$ & E01ARG & $\$ 57.733$ & $\$ 2.124$ \\
\hline 02AUS & Australia & M02AUS & $\$ 189.406$ & E02AUS & $\$ 189.630$ & $\$ 0.224$ \\
\hline 03BRA & Brazil & M03BRA & $\$ 137.552$ & E03BRA & $\$ 185.235$ & $\$ 47.683$ \\
\hline 04CAN & Canada & M04CAN & $\$ 402.966$ & E04CAN & $\$ 389.071$ & $\$-13.895$ \\
\hline $05 \mathrm{CHI}$ & China & M05CHI & $\$ 1587.921$ & E05CHI & $\$ 2097.637$ & $\$ 509.716$ \\
\hline 06FRA & France & M06FRA & $\$ 560.555$ & E06FRA & $\$ 488.885$ & $\$-71.670$ \\
\hline 07GER & Germany & M07GER & $\$ 1060.672$ & E07GER & $\$ 1340.752$ & $\$ 280.080$ \\
\hline 08IDI & India & M08IDI & $\$ 356.705$ & E08IDI & $\$ 260.327$ & $\$-96.378$ \\
\hline 09 IDO & Indonesia & M09IDO & $\$ 135.653$ & E09IDO & $\$ 144.490$ & $\$ 8.837$ \\
\hline 10ITA & Italy & M10ITA & $\$ 404.578$ & E10ITA & $\$ 461.529$ & $\$ 56.951$ \\
\hline 11JAP & Japan & M11JAP & $\$ 606.924$ & E11JAP & $\$ 644.932$ & $\$ 38.008$ \\
\hline $12 \mathrm{MEX}$ & Mexico & M12MEX & $\$ 387.064$ & E12MEX & $\$ 373.893$ & $\$-13.172$ \\
\hline 13RUS & Russia & M13RUS & $\$ 182.262$ & E13RUS & $\$ 285.491$ & $\$ 103.229$ \\
\hline $14 \mathrm{SAU}$ & Saudi Arabia & M14SAU & $\$ 129.796$ & E14SAU & $\$ 207.572$ & $\$ 77.776$ \\
\hline $15 \mathrm{SAF}$ & South Africa & M15SAF & $\$ 74.744$ & E15SAF & $\$ 74.111$ & $\$-0.633$ \\
\hline 16TUR & Turkey & M16TUR & $\$ 198.618$ & E16TUR & $\$ 142.530$ & $\$-56.089$ \\
\hline 17UKM & $\begin{array}{l}\text { United } \\
\text { Kingdom }\end{array}$ & M17UKM & $\$ 636.368$ & E17UKM & $\$ 411.463$ & $\$-224.905$ \\
\hline 18USA & United States & M18USA & $\$ 2248.209$ & E18USA & $\$ 1450.457$ & $\$-797.752$ \\
\hline
\end{tabular}

Considering now countries with a higher positive absolute trade balance, there is in first place from decreasing to increasing amounts, Brazil, with a positive trade balance of $\$ 47.683$ billion US dollars. That would mean for them to pay $25.74 \%$ of their exports. Then follows Saudi Arabia, with a positive trade balance of $\$ 77.776$ billion US dollars, which would mean for them to pay $37.47 \%$ of their exports. In third place is Russia, with a positive trade balance of $\$ 103.229$ billion US dollars, meaning for them they should pay $36.16 \%$ of their exports. In fourth place is Germany, with a positive trade balance of $\$ 280.080$ billion US dollars. Germany would have to pay $20.89 \%$ of their exports on tariffs to other countries. Finally, there is China, with a positive trade balance of $\$ 509.716$ billion US dollars. If we wanted each and all G18 nations in the world to have zero trade balance, China would have to pay $24.30 \%$ of their exports to countries who receive such exports. The problem of course is how to make such arrangements, even if it were possible to demand such compensatory payments, because it would be difficult to ascertain who should get how much paid to who.

My students are working on the case of Mexico (who has a slightly negative trade balance, meaning their imports are higher than their exports). They are considering analyzing all matching sectors for imports and exports. Initial results indicate that in order to make a specific sector trade balance neutral requires in some cases very high tariffs on imports, even if the overall trade deficit of Mexico is very small (actually the second smallest in absolute value of all 18 
Table 3. Results summary for the tariffs problem.

\begin{tabular}{llll}
\hline \multicolumn{1}{c}{ Tariffs on imports } & \multicolumn{2}{c}{ Tariffs on exports } \\
\hline M01ARG & $0.00 \%$ & E01ARG & $3.68 \%$ \\
M02AUS & $0.00 \%$ & E02AUS & $0.12 \%$ \\
M03BRA & $0.00 \%$ & E03BRA & $25.74 \%$ \\
M04CAN & $3.45 \%$ & E04CAN & $0.00 \%$ \\
M05CHI & $0.00 \%$ & E05CHI & $24.30 \%$ \\
M06FRA & $12.79 \%$ & E06FRA & $0.00 \%$ \\
M07GER & $0.00 \%$ & E07GER & $20.89 \%$ \\
M08IDI & $27.02 \%$ & E08IDI & $0.00 \%$ \\
M09IDO & $0.00 \%$ & E09IDO & $6.12 \%$ \\
M10ITA & $0.00 \%$ & E10ITA & $12.34 \%$ \\
M11JAP & $0.00 \%$ & E11JAP & $5.89 \%$ \\
M12MEX & $3.40 \%$ & E12MEX & $0.00 \%$ \\
M13RUS & $0.00 \%$ & E13RUS & $36.16 \%$ \\
M14SAU & $0.00 \%$ & E14SAU & $37.47 \%$ \\
M15SAF & $0.85 \%$ & E15SAF & $0.00 \%$ \\
M16TUR & $28.24 \%$ & E16TUR & $0.00 \%$ \\
M17UKM & $35.34 \%$ & E17UKM & $0.00 \%$ \\
M18USA & $35.48 \%$ & E18USA & $0.00 \%$ \\
\hline
\end{tabular}

countries being considered for 2016). In the case of the oil industry, there should be, for 2016, a tariff on imports of approximately $55 \%$ of the value of the sector. This makes no sense, since it would mean increasing the price of gasoline, for example, by $55 \%$. Consider another example (not included in the analysis made here): Switzerland. They produce literally no milk, which would theoretically mean for them to pay $100 \%$ on milk imports. However, nobody doubts that Nestlé is a very powerful chocolate and related articles producing company. Today, large corporation have more power than even single nations. I may even dare to challenge the power of the country with the highest GDP in 2016, the USA, compared to large corporations. A lot of power has been given to these companies. I believe it is important, even for the USA, to consider the possibility of forming economic blocks, in order to be able to put a balancing check against the power of large corporate conglomerates. The North American Free Trade Agreement (NAFTA) may fall short of what the future may bring. I dare proposing even the possibility of a Union of the Americas (not American Union so that nobody confuses this proposal with the Monroe doctrine: "America for the Americans"). America has five countries belonging to the group of 20 (G20): Canada, Mexico, USA, Brazil and Argentina. If it were possible to have Brazil joining such concert of nations without trying to make it all about Brazil gaining too big an importance in South America (which undoubtedly it has) and rather contributing to the common goals of America, understanding by America not only the USA, but Canada, the USA and Latin America. It may be possible to 
create a currency common to Latin America, which I propose to call the LAT (Latin American peso), which should be weighted versus the US and Canadian dollars, in a way similar to the Euro in Europe when compared to the British Pound in the United Kingdom. Something called the "Big Mac Index" can be used as a way to reasonably value the LAT of the countries involved in Latin America when compared to the value of their national currencies, which should not disappear, but rather coexist with the LAT, at least during a few decades of transition from one system to another or even continue having local currencies if the spirit of the LAT valuation mechanism is taken at face value. I did some work on something called the PAL (Pacific Alliance dollar) in a paper that may be of interest in this context [15].

What about the cases of trade deficits? The lowest on absolute value of all trade deficits belongs to South Africa, with $\$-0.633$ billion US dollars. Such trade deficit would mean to impose tariffs on imports of $0.85 \%$. Almost the "ideal” case. The second lowest trade deficit belongs to Mexico: $\$-13.172$ billion US dollars, meaning tariffs on imports of $3.40 \%$. Then follows Canada, with a trade deficit of $\$-13.895$ billion US dollar, meaning tariffs on imports of $3.45 \%$. Still reasonable enough. However, from this point on, things get complicated. Following is Turkey, with a trade deficit in 2016 of \$-56.089 billion US dollars. For an economy the size of Turkey, that would mean imposing tariffs on imports of $28.24 \%$, which starts to sound unreasonable. France also has a relatively high trade deficit of $\$-71.670$ billion US dollars, which would mean tariffs on imports of $12.79 \%$, which is not as bad as Turkey considering the relative sizes of the economies of these two countries. Then follows India, with a trade deficit of \$-96.378 billion US dollars, meaning tariffs on imports of $27.02 \%$. There is also the case of the United Kingdom, having a trade deficit of \$-224.905 billion US dollars in 2016, which would require them to have tariffs on imports of $35.34 \%$. Finally, there is the case of the USA, with a trade deficit, in 2016, of \$-797.752 billion US dollars, meaning, even in the case of an economy of the size of the United States, tariffs on imports of $35.48 \%$. Clearly, it is unreasonable to expect the UK or the USA to impose tariffs on imports in the order of 35\%. The tariffs on Steel (25\%) and Aluminum (10\%) imposed on China have a relatively long history of a somewhat documented dumping commercial policy, which is illegal even in the case of the World Trade Organization (WTO: https://www.wto.org/). This is because China receives a lot of US dollars, by the way thanks to their trade surplus with the USA. China does not even know what to do with all that money. Although money in such amounts matters, and matters considerably, imposing trade tariffs on China in the order of $35 \%$ is unreasonable, because that would tend to create inflationary pressures on US imports from China, which allow the US to maintain high quality and relatively low prices in a lot of commodities.

\section{Conclusions}

What can be done? From a mercantilist perspective, the idea is to ensure that the 
national security interests of the United States and the United Kingdom do not become compromised. For example, consider the case of IBM. When the Chinese offered IBM to buy it, the people at IBM realized that in the twenty first century, what matters is the creation of basic science and technology (knowledge, that is, applied or not). Thus, IBM was split in two: IBM sales and IBM research. IBM sales even did not allow the Chinese to sell computers using the IBM trademark. Although the technology to produce computers based on a Windows platform (desktop and laptop) was transferred, the Chinese had to create their own brand name: Lenovo. I see, from time to time, very cheap Lenovo computers offered in stores and even among my students. Was that bad for the world? Probably not. In the meantime, IBM research created Watson, winning the Jeopardy contest not that long ago (around 2013). IBM continues to create state of the art software (examples are SPSS-Statistical Package for the Social Sciences-and AMOS-Analysis of Moment Structures-) and state of the art research in the software and computer industries.

From a Keynesian point of view, if the country does not compromise its ability to pay for their trade deficit (a deep discussion on currencies and the policies surrounding them would be due), because they receive, for example, a considerable amount of money in transfers from other countries who want to invest in the USA or the UK, the overall balance of payments (which includes the trade balance but also financial movements of capital) may support such trade deficits. Clearly, an ongoing analysis of the situation as it progresses is necessary and this paper simply attempts to provide a methodology for analyzing "optimal" trade tariffs that may never actually be imposed. Further research on the topic is required.

\section{References}

[1] Kantorovich, L.V. (1940) A New Method of Solving Some Classes of Extremal Problems. Doklady Akademii Nauk SSSR, 28, 211-214.

[2] Dantzig, G. (1951a) Application of the Simplex Method to a Transportation Problem. In: Koopmans, T., Ed., Activity Analysis of Production and Allocation, John Wiley and Sons, New York, 359-373.

[3] Dantzig, G. (1951b) A Proof of the Equivalence of the Programming Problem and the Game Problem. In: Koopmans, T., Ed., Activity Analysis of Production and Allocation, John Wiley and Sons, New York, 330-335.

[4] Dantzig, G. (1963) Linear Programming and Extensions. Princeton University Press, Princeton. https://doi.org/10.1515/9781400884179

[5] Dantzig, G.B. and Thapa, M.N. (1997) Linear Programming 1: Introduction. Springer-Verlag, Berlin.

[6] Dantzig, G.B. and Thapa, M.N. (2003) Linear Programming 2: Theory and Extensions. Springer-Verlag, Berlin.

[7] Cottle, R.W., Ed. (2003) The Basic George B. Dantzig. Stanford University Press, Stanford.

[8] Vanderbei, R.J. (2008) Linear Programming: Foundations and Extensions. 3rd Edition, Springer, Berlin. https://doi.org/10.1007/978-0-387-74388-2 
[9] Bland, R.G. (1977) New Finite Pivoting Rules for the Simplex Method. Mathematics of Operations Research, 2, 103-107. https://doi.org/10.1287/moor.2.2.103

[10] Borgwardt, K.-H. (1987) The Simplex Algorithm: A Probabilistic Analysis, Algorithms and Combinatorics, Volume 1. Springer-Verlag, Berlin.

[11] Kirton, J.J. (2013) G20 Governance for a Globalized World. Global Finance Series. Routledge, Abingdon.

[12] International Trade Center (2018) International Trade in Goods-Imports 2001-2017. http://www.intracen.org/itc/market-info-tools/statistics-import-country-product/

[13] International Trade Center (2018) International Trade in Goods-Exports 2001-2017. http://www.intracen.org/itc/market-info-tools/statistics-export-country-product/

[14] International Monetary Fund (2017) World Economic Outlook Database. http://www.imf.org/external/pubs/ft/weo/2017/01/weodata/weorept.aspx?sy=2016\& $\underline{\text { ey }=2016 \& s s d=1 \& \text { sort }=\text { country\&ds }=. \& b r=1 \& p r 1 . x=50 \& p r 1 . y=6 \& c=213 \% 2 \mathrm{C} 193 \% 2}$ C273\%2C223\%2C156\%2C924\%2C922\%2C456\%2C132\%2C199\%2C134\%2C534\%2 C536\%2C136\%2C186\%2C158\%2C112\%2C542\%2C111\&s=NGDPD\%2CNGDPDPC \%2CPPPGDP\%2CPPPPC\%2CLP\&grp=0\&a

[15] Copertari, L.F. (2016) Emerging Markets and the Pacific Alliance. Open Access Library Journal, 3, e2919. https://doi.org/10.4236/oalib.1102919 


\section{Appendix A: Lindo/Lingo Model}

$$
\begin{aligned}
& \text { MINIMIZE + M01ARG } \\
& + \text { M02AUS } \\
& + \text { M03BRA } \\
& + \text { M04CAN } \\
& +\mathrm{M} 05 \mathrm{CHI} \\
& + \text { M06FRA } \\
& + \text { M07GER } \\
& + \text { M08IDI } \\
& + \text { M09IDO } \\
& + \text { M10ITA } \\
& + \text { M11JAP } \\
& + \text { M12MEX } \\
& + \text { M13RUS } \\
& + \text { M14SAU } \\
& + \text { M15SAF } \\
& + \text { M16TUR } \\
& + \text { M17UKM } \\
& + \text { M18USA } \\
& + \text { E01ARG } \\
& + \text { E02AUS } \\
& + \text { E03BRA } \\
& + \text { E04CAN } \\
& +\mathrm{E} 05 \mathrm{CHI} \\
& + \text { E06FRA } \\
& + \text { E07GER } \\
& + \text { E08IDI } \\
& + \text { E09IDO } \\
& + \text { E10ITA } \\
& \text { + E11JAP } \\
& + \text { E12MEX } \\
& + \text { E13RUS } \\
& + \text { E14SAU } \\
& + \text { E15SAF } \\
& + \text { E16TUR } \\
& + \text { E17UKM } \\
& + \text { E18USA }
\end{aligned}
$$

\section{SUBJECT TO}

$$
\begin{aligned}
& + \text { 57.733 E01ARG }-55.610 \mathrm{M} 01 \mathrm{ARG}=2.124 \\
& +189.630 \text { E02AUS }-189.406 \mathrm{M} 02 \mathrm{AUS}=0.224 \\
& +185.235 \text { E03BRA }-137.552 \mathrm{M} 03 \mathrm{BRA}=47.683
\end{aligned}
$$




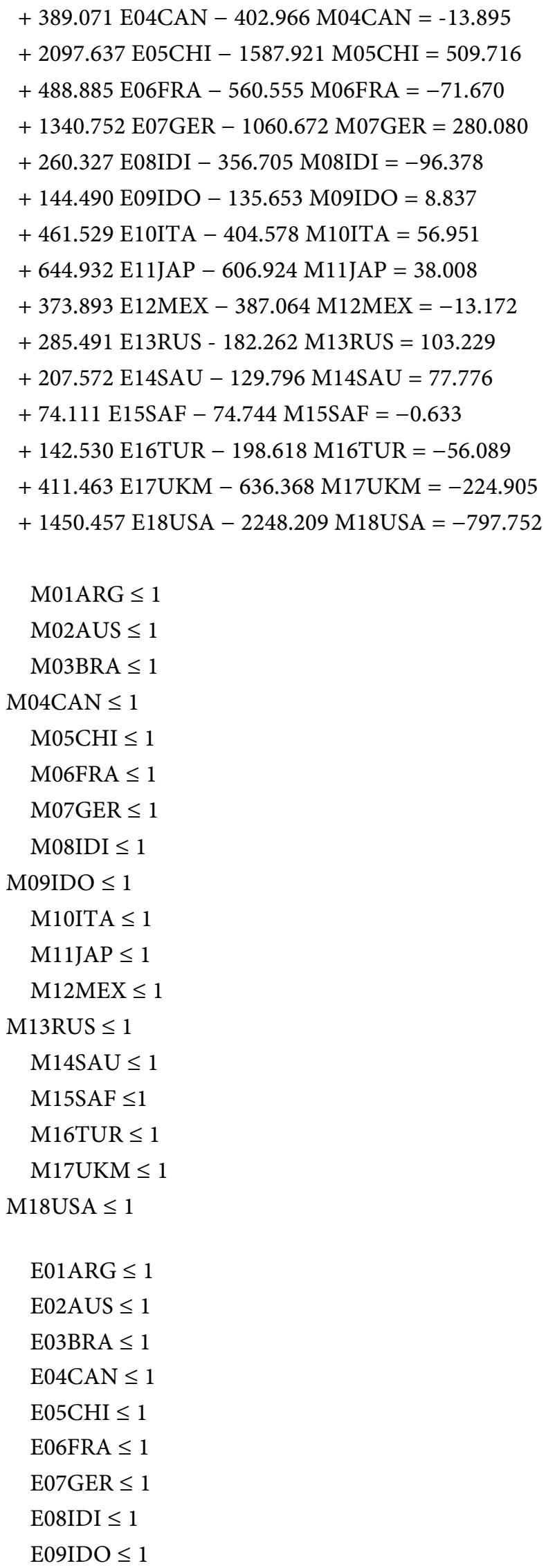


E10ITA $\leq 1$

E11JAP $\leq 1$

E12MEX $\leq 1$

E13RUS $\leq 1$

E14SAU $\leq 1$

E $15 S A F \leq 1$

E16TUR $\leq 1$

E17UKM $\leq 1$

E18USA $\leq 1$

END 


\section{Appendix B: Lindo/Lingo Output}

Global optimal solution found.

Objective value:

3.192732

Infeasibilities:

0.000000

Total solver iterations:

Elapsed runtime seconds:

0.05

Model Class:

Total variables:

Nonlinear variables:

36

Integer variables:

0

Total constraints:

55

Nonlinear constraints:

0

Total nonzeros:

108

Nonlinear nonzeros:

0

$\begin{array}{lcc}\text { Variable } & \text { Value } & \text { Reduced Cost } \\ \text { M01ARG } & 0.000000 & 1.963227 \\ \text { M02AUS } & 0.000000 & 1.998819 \\ \text { M03BRA } & 0.000000 & 1.742581 \\ \text { M04CAN } & 0.3448182 \mathrm{E}-01 & 0.000000 \\ \text { M05CHI } & 0.000000 & 1.757005 \\ \text { M06FRA } & 0.1278554 & 0.000000 \\ \text { M07GER } & 0.000000 & 1.791102 \\ \text { M08IDI } & 0.2701897 & 0.000000 \\ \text { M09IDO } & 0.000000 & 1.938840 \\ \text { M10ITA } & 0.000000 & 1.876604 \\ \text { M11JAP } & 0.000000 & 1.941067 \\ \text { M12MEX } & 0.3403055 \mathrm{E}-01 & 0.000000 \\ \text { M13RUS } & 0.000000 & 1.638416 \\ \text { M14SAU } & 0.000000 & 1.625306 \\ \text { M15SAF } & 0.8468907 \mathrm{E}-02 & 0.000000 \\ \text { M16TUR } & 0.2823964 & 0.000000 \\ \text { M17UKM } & 0.3534197 & 0.000000 \\ \text { M18USA } & 0.3548389 & 0.000000 \\ \text { E01ARG } & 0.3679005 \mathrm{E}-01 & 0.000000 \\ \text { E02AUS } & 0.1181248 \mathrm{E}-02 & 0.000000 \\ \text { E03BRA } & 0.2574190 & 0.000000 \\ \text { E04CAN } & 0.000000 & 1.965518 \\ \text { E05CHI } & 0.2429953 & 0.000000\end{array}$




$\begin{array}{lcc}\text { E06FRA } & 0.000000 & 1.872145 \\ \text { E07GER } & 0.2088977 & 0.000000 \\ \text { E08IDI } & 0.000000 & 1.729810 \\ \text { E09IDO } & 0.6115994 \mathrm{E}-01 & 0.000000 \\ \text { E10ITA } & 0.1233964 & 0.000000 \\ \text { E11JAP } & 0.5893334 \mathrm{E}-01 & 0.000000 \\ \text { E12MEX } & 0.000000 & 1.965972 \\ \text { E13RUS } & 0.3615841 & 0.000000 \\ \text { E14SAU } & 0.3746941 & 0.000000 \\ \text { E15SAF } & 0.000000 & 1.991531 \\ \text { E16TUR } & 0.000000 & 1.717609 \\ \text { E17UKM } & 0.000000 & 1.646580 \\ \text { E18USA } & 0.000000 & 1.645161\end{array}$

\begin{tabular}{lcc} 
Row & Slack or Surplus & \multicolumn{1}{c}{ Dual Price } \\
1 & 3.192732 & -1.000000 \\
2 & 0.000000 & $-0.1732112 \mathrm{E}-01$ \\
3 & 0.000000 & $-0.5273427 \mathrm{E}-02$ \\
4 & 0.000000 & $-0.5398548 \mathrm{E}-02$ \\
5 & 0.000000 & $0.2481599 \mathrm{E}-02$ \\
6 & 0.000000 & $-0.4767269 \mathrm{E}-03$ \\
7 & 0.000000 & $0.1783946 \mathrm{E}-02$ \\
8 & 0.000000 & $-0.7458501 \mathrm{E}-03$ \\
9 & 0.000000 & $0.2803437 \mathrm{E}-02$ \\
10 & 0.000000 & $-0.6920894 \mathrm{E}-02$ \\
11 & 0.000000 & $-0.2166711 \mathrm{E}-02$ \\
12 & 0.000000 & $-0.1550551 \mathrm{E}-02$ \\
13 & 0.000000 & $0.2583552 \mathrm{E}-02$ \\
14 & 0.000000 & $-0.3502737 \mathrm{E}-02$ \\
15 & 0.000000 & $-0.4817605 \mathrm{E}-02$ \\
16 & 0.000000 & $0.1337900 \mathrm{E}-01$ \\
17 & 0.000000 & $0.5034790 \mathrm{E}-02$ \\
18 & 0.000000 & $0.1571418 \mathrm{E}-02$ \\
19 & 0.000000 & $0.4447985 \mathrm{E}-03$ \\
20 & 1.000000 & 0.000000 \\
21 & 1.000000 & 0.000000 \\
22 & 1.000000 & 0.000000 \\
23 & 0.9655182 & 0.000000 \\
24 & 1.000000 & 0.000000 \\
25 & 0.8721446 & 0.000000 \\
26 & 1.000000 & 0.000000 \\
27 & 0.7298103 & 0.000000 \\
28 & 1.000000 & 000000 \\
& &
\end{tabular}




$\begin{array}{lrl}29 & 1.000000 & 0.000000 \\ 30 & 1.000000 & 0.000000 \\ 31 & 0.9659695 & 0.000000 \\ 32 & 1.000000 & 0.000000 \\ 33 & 1.000000 & 0.000000 \\ 34 & 0.9915311 & 0.000000 \\ 35 & 0.7176036 & 0.000000 \\ 36 & 0.6465803 & 0.000000 \\ 37 & 0.6451611 & 0.000000 \\ 38 & 0.9632099 & 0.000000 \\ 39 & 0.9988188 & 0.000000 \\ 40 & 0.7425810 & 0.000000 \\ 41 & 1.000000 & 0.000000 \\ 42 & 0.7570047 & 0.000000 \\ 43 & 1.000000 & 0.000000 \\ 44 & 0.7911023 & 0.000000 \\ 45 & 1.000000 & 0.000000 \\ 46 & 0.9388401 & 0.000000 \\ 47 & 0.8766036 & 0.000000 \\ 48 & 0.9410667 & 0.000000 \\ 49 & 1.000000 & 0.000000 \\ 50 & 0.6384159 & 0.000000 \\ 51 & 0.6253059 & 0.000000 \\ 52 & 1.000000 & 0.000000 \\ 53 & 1.000000 & 0.000000 \\ 54 & 1.000000 & 0.000000 \\ 55 & 1.000000 & 0.000000\end{array}$

